\title{
INFLUENCE OF PSC CHANGES IN THE UPSTREAM SECTOR FROM COST RECOVERY SYSTEM INTO GROSS SPLIT TOWARDS THE OBLIGATION TO PAY LAND AND BUILDING TAX*
}

\author{
Irine Handika** \\ Department of Tax Law, Faculty of Law Universitas Gadjah Mada \\ Jalan Socio Justicia No. 1, Bulaksumur, Sleman, D.I. Yogyakarta 55281
}

\begin{abstract}
The scheme of profit sharing contracts has been significantly changed due to the enactment of Permen ESDM No. 8/2017 Concerning the Gross Split Revenue Sharing Contract on January 16, 2017.This research focused on: First, the relationship between the change of PSC Cost Recovery form to PSC Gross Split with the mechanism of Administration of Land and Building Tax and its addressat; and Both relationship between change of PSC Cost Recovery form PSC Gross Split with procedure of PBB calculation at exploration and exploitation stage.
\end{abstract}

Keywords: production sharing contract, land and building tax, cost recovery, gross split.

\section{Intisari}

Skema kontrak bagi hasil mengalami perubahan yang sangat signifikan akibat diundangkannya Permen ESDM No. 8/2017 Tentang Kontrak Bagi Hasil Gross Split pada tanggal 16 Januari 2017. Penelitian ini difokuskan pada: Pertama, hubungan antara perubahan bentuk PSC Cost Recovery menjadi PSC Gross Split dengan mekanisme penatausahaan Pajak Bumi dan Bangunan dan addressat-nya; dan Kedua hubungan antara perubahan bentuk PSC Cost Recovery menjadi PSC Gross Split dengan tata cara perhitungan PBB pada tahap eksplorasi dan eksploitasi.

Kata kunci: production sharing contract, pajak bumi dan bangunan, cost recovery, gross split.

\section{Pokok Muatan}

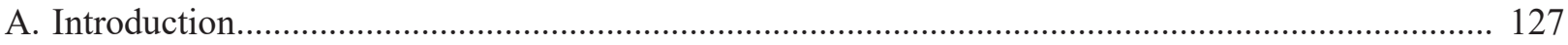

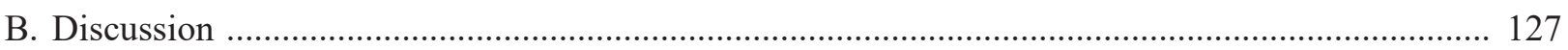

1. The Essence of Cost Recovery in Production Sharing Contracts and Cost Recovery Restrictions in Production Sharing Contracts in Indonesia

2. Administration of Land and Building Tax in the Era Production Sharing Contract Cost Recovery

3. Background of PSC Cost Recovery Amandment into PSC Gross Split

4. Administration of Land and Building Tax in the Era Production Sharing Contract Gross Split . 135

C. Conclusion

Research Result, funded by Faculty of Law Universitas Gadjah Mada, 2017.

Correspondence address: irinehandika@ugm.ac.id. 


\section{A. Introduction}

The petroleum industry is broadly differentiated based on the scope of its activities, namely upstream and downstream. The petroleum downstream industry is related to the distribution chain to ensure oil reaches all of its consumers, while the upstream industry includes exploration and exploitation, which is related to the stages of finding, finding, and extracting crude oil from the wellhead.

In the upstream industry there is a legal relationship arising from access to petroleum between the Government as the representation of the state and the Investor. Such relations can be arranged through two instruments, namely concessions or contracts. The weakness of the concession system is that state ownership is limited to petroleum reserves that are under the surface of the earth, but when oil reaches the wellhead there is a transfer of ownership to investors. This background gave birth to a system of contracts as a new scheme in Law No. 22 of 2001 concerning Oil and Gas termes Cooperation Contracts. The form of the contract system can be varied, one of which is the Production Sharring Contract (hereinafter PSC) used in Indonesia. In this context, investors (Contractors) are not dominant because ownership of oil remains in the country.

In early 2017 the cost recovery system used in the PSC experienced a very significant change due to the promulgation of the Minister of Energy and Mineral Resources No. 8 of 2017 concerning Production Sharing Contracts Gross Split (PSC Gross Split) on January 16, 2017. Article 1 Number 7 Candy a quo defines the PSC as "Contract based on the principle of gross production division without a mechanism for returning operating costs". This research will focus on two research questions, namely: First, the relationship between changes in the form of PSC Cost Recovery becomes a PSC Gross Split with the mechanism for administering
Land and Building Tax and its addressat; and Second is the relationship between the change in the form of the Cost Recovery PSC to the PSC Gross Split with the procedures for calculating the Land and Building Tax, which in this sector are distinguished between the Land and Building Tax exploration and exploitation stages.

\section{B. Discussion}

1. The Essence of Cost Recovery in Production Sharing Contracts and Cost Recovery Restrictions in Production Sharing Contracts in Indonesia

Production Sharing Contracts are translated and rearranged to become more general by Law No. 22 of 2001 concerning Oil and Gas (Oil and Gas Law). The scope is expanded through the term of Cooperation Contract. ${ }^{1}$ Contracts in general can be in the form of Production Sharing Contracts (PSC) or other forms of cooperation contracts that are considered more beneficial for the State. ${ }^{2}$ The essence with the regime of PSC, Pertamina Law is still the same, even though there are two major substantive changes, namely: State Companies (Pertamina) are no longer holders of Mining Authorities but are transformed into Contractors, the same as other private companies. As a result, the parties in the PSC became the Government represented by Special Task Force for Upstream Oil and Gas Business Activities (Satuan Kerja Khusus Pelaksana Kegiatan Usaha Hulu Minyak dan Gas Bumi, hereinafter SKK Migas) or formerly known as Executive Agency for Upstream Oil and Gas Activity (BP Migas) to make a contract with the Contractor. The second amendment, the Contractor is required to pay a number of taxes and other state levies which will be discussed later.

Furthermore, the Oil and Gas Law does not explain the intent of the phrase "other cooperation contracts" in order to provide flexibility in regulation that is adjusted to the dynamics of the needs of

The normative definition of Work Area according to Article 1 number 16 of Act Number 22 of 2001 is "Certain regions within the Indonesian Mining Law Area for the implementation of Exploration and Exploitation."

See Article 1 number 19 of Law Number 22 of 2001 concerning Oil and Gas (State Gazette of the Republic of Indonesia of 2001 Number 136 , Supplement to the State Gazette of the Republic of Indonesia Number 4152). 
the state and investors. However, the form of the contract was chosen which was the most profitable for the country.

In the prevailing international practice, there are three alternative forms of other cooperation contracts referred to above. Following are the three elaborations: ${ }^{3}$

a. Service Contract, i.e. contracts that are based on service performance so that the return on contractor fees is carried out in the form of cash and not in kind. However, the Contractor can be given the option of buy back a number of crude oil produced according to market prices.

b. Pure Service Contract, namely contracts for providing technical assistance services carried out for a certain period. The government gives fees to production-based contractors, for example $1 \$ /$ barrel for each barrel produced.

c. Risk Service Contract, a contract of service delivery in which the government provides a service fee in the form of cash not in kind.

The above elaboration can be described as shown below.

Figure 1. Contract Categorization

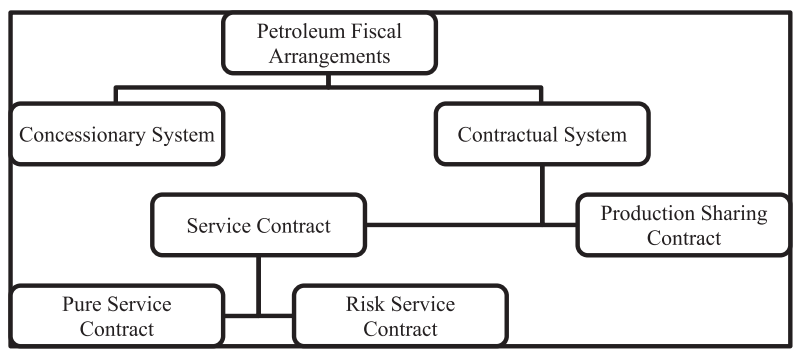

Source: PWC, 2012

The choice of contract form is based on the economics of the project which is influenced by several factors, including: oil and gas reserves, production profile, difficulty level of work area, production costs, and oil and gas prices. Oil and gas producing countries that have abundant reserves and technically easy work areas generally choose to use a Service Contract scheme. In contrast to Indonesia, the number of productions does not generally use the PSC scheme.

The version of PSC under the Oil and Gas Law stipulates a number of state revenue obligations that must be deposited by the Contractors, both in the form of Taxes and Non-Tax State Revenues. As mentioned in Article 31 paragraph (2) of the Law $a$ quo has regulated state revenues in the form of taxes consisting of: (a) taxes; (b) import duties, and other charges on imports and taxes; and (c) regional taxes and regional levies.

Moreover, the type of Taxes and Non-Tax State Revenues set forth in paragraph (3) consists of: (a) part of the country; (b) state levies in the form of permanent contributions and exploration and exploitation contributions; and (c) bonuses.

Regulators provide options for upstream oil and gas industry players to choose which provisions are used as references in implementing their tax obligations. The contractor can choose to be carried out in accordance with the provisions of the laws and regulations in the field of taxation that apply when the PSC is signed; or dynamically follow the applicable provisions of legislation in the field of taxation. The Oil and Gas Law delegates the authority to further regulate the determination of the size of the state, state levies, and bonuses, as well as the procedures for depositing them to the Government by Government Regulation.

The PSC has historically existed since 1966 in collaboration between Independence Indonesian American Oil Company (IIAPCO) and Permina (now Pertamina). However, the PSC has no legal basis because Law No. 44 / Prp / 1960 concerning Oil and Natural Gas Mining only knows the Work Agreement. Its legality only came into existence in 1971 through Law No. 8/1971 concerning the State

Benny Lubiantara, 2012, Ekonomi Migas: Tinjauan Aspek Komersial Kontrak Migas, Gramedia, Jakarta, pp. 8-9. 
Oil and Gas Mining Company. The Indonesian version of PSC has several core characteristics such as the following: ${ }^{4}$

a. Oil as a non-renewable strategic natural resource contained in the Indonesian Mining Law Area constitutes national wealth controlled by the state;

b. Ownership of oil is in the hands of the government up to the point of export;

c. The contractor is obliged to bring capital and technology and to bear the operational risks in the context of carrying out petroleum operations;

d. The contractor regains cost recovery in accordance with the work plan and budget, after the work area produces commercial production.

Production Sharing Contract (PSC) is the most common type of contract in the exploration and development of the petroleum industry in Indonesia. In a PSC, the Contractor assumes all risks and costs for conducting exploration, development and production. As a return, if exploration is successful, in addition to having the opportunity to recover investment from production (hydrocarbon costs), the Contractor also receives part of the production as stated in the agreement, after deducting cost recovery (profit hydrocarbon). Reserves together with cost recovery plus profit hydrocarbons that can be replaced during the term of the contract will be reported by the upstream oil and gas contractor. ${ }^{5}$

One system of profit sharing that is very close to the implementation of Production Sharing Contracts in Indonesia is Cost Recovery. The revenue sharing system between the Government and the Contractor occurred after it was previously reduced by Cost Recovery. Cost Recovery is the return of oil and gas exploration and exploitation costs from the Government to the Contractor. The Cost Recovery is paid in the form of oil and gas production, which is assessed by a Weighed Average Price (WAP), which is a weighted average price calculated based on the lifting value for one year divided by the number of lifting units during the same period. ${ }^{6}$

Based on the explanation above, it can be said that Cost Recovery is the cost paid by the Government to contractors as a replacement for production and investment costs during the process of exploration, exploitation and development of oil and gas blocks being worked on in a country's territory. ${ }^{7}$ So, after oil production began to run, some of the results became the contractor's ration in exchange for the costs incurred during the exploration process. ${ }^{8}$

As for clarifying the following, the flow of the PSC is described which includes a cost recovery scheme.

\section{Figure 2. PSC Cost Recovery Scheme}

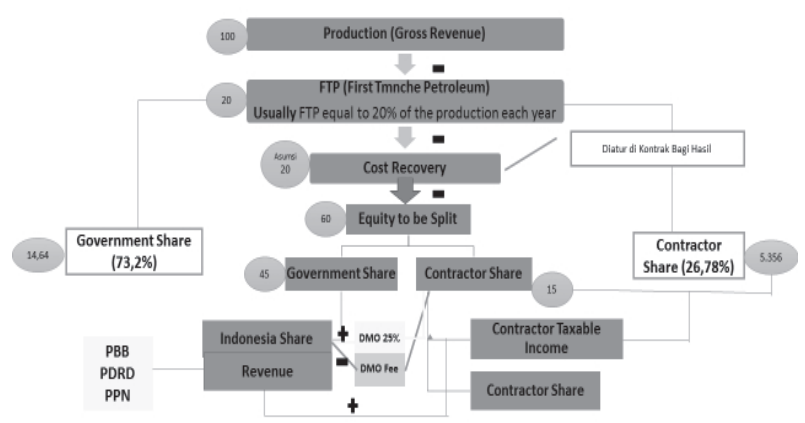

Source: compiled by Authors from various sources.

The above scheme has been used since Law No. 8 Number 1971 concerning the State Oil and Gas Mining Company promulgated. But lately, the scheme has undergone very significant

\footnotetext{
It was concluded by the author based on the norms contained in Law Number 22 Year 2001 concerning Oil and Gas (State Gazette of the Republic of Indonesia of 2001 Number 136, Supplement to the State Gazette of the Republic of Indonesia Number 4152) and Government Regulation Number 79 of 2010 concerning Operating Costs Which Can Be Returned and Treatment of Income Tax in the Upstream Business Field of Oil and Gas (State Gazette of the Republic of Indonesia of 2010 Number 139, Supplement to the State Gazette of the Republic of Indonesia Number 5173).

Ety Syamsiah Ariyati, 2010, Analisis Ketentuan-Ketentuan di Production Sharing Contract Indonesia dalam Kaitannya dengan Penerimaan Negara Minyak dan Gas Bumi, Thesis, University of Indonesia, p. 14.

6 Abdul Nasir, 2014, as cited by Shofia Shobah, 2015, Cost Recovery dalam Kontrak Kerjasama Minyak dan Gas Bumi di Indonesia Ditinjau dari Hukum Kontrak Internasional, Thesis, Faculty of Law, Brawijaya University, p. 14.

Nordin Satrio as cited by Shofia Shobah, Ibid., p. 4.

George D.R. Hormat as cited by Shofia Shobah, Ibid.
} 
changes due to the promulgation of Minister of Energy and Mineral Resources No. 8 Number 2017 concerning Gross Split Production Sharing Contract (hereinafter, PSC Gross Split) on January 16, 2017. Article 1 Number 7 Candy a quo defines the PSC as "Contract based on the principle of gross division of production without a mechanism for returning operating costs".

The government argues that the PSC Gross Split was chosen as a way to stop state leakage due to cost recovery. This scheme is considered likely to be corrupt because it does not have a clear threshold. The Audit of the Supreme Audit Agency showed that during 2000-2008 the potential for state losses due to the imposition of an incorrect cost recovery in the oil and gas sector reached Rp345.996 trillion per year or 1.7 billion rupiah per day. ${ }^{9}$

\section{Administration of Land and Building Tax in the Era Production Sharing Contract Cost Recovery}

As illustrated in the Figure 2, it appears that UN payments are not calculated from the Contractor's part but from the State. However, the administration mechanism differs between contractors operating under the PSC signed before 2010 and post 2010. For contractors operating under the PSC signed before 2010, they use the assume and discharge scheme. Simply put in the form of overbooking where the Directorate General of Taxes takes into account the tax payable based on data in the Tax Object Notice provided by the Contractor, which is then billed to the Directorate General of Financial Institutions which is now changed to the Directorate General of State Assets. The Directorate General of State Assets will then pay the outstanding debts by transferring the amount owed from the state revenue to be stated in the the Directorate General of Taxes' books. In a nutshell, enter from the right pocket and out of the left pocket.

The legal basis of the assume and discharge scheme is the Decree of the Minister of Finance No. 451/KMK.04/1997 concerning the Administration of Tax Object Data on Land and Buildings of Oil and Gas and Geothermal Mining and Payment determined on August 28, 1997. In Article 3 of the Decree of the Minister of $a$ quo "The determination of the amount of Land and Building Tax payable on the Land and Building Tax object of Oil and Gas and Geothermal Mining is carried out by the Director General of Taxes". Further information regarding the payment is regulated in Article 4 as follows:

Based on the request submitted by the Director General of Taxes, the Director General of Financial Institutions transfers the portion of the obligation to Deposit Net Business Income (Net Operating Income) to the State Cash Office Account q.q. Land and Building Tax at the Bank/Post Office and Operational Current $\mathrm{V}$ for each of the relevant Level II Regions.

The further implementation of operational techniques for administering Oil and Gas Taxes is regulated by the Director General of Taxes, as stated in Article 5. This provision is followed up with the issuance of the Director General of Taxes Decree No. Kep-19/Pj.6/1997 concerning Procedures for Administration of Tax Object Data on Land and Buildings of Oil and Gas and Geothermal Mining and Payment as determined on October 22, 1997. Following are illustrations of administration of payment for Land and Building Tax in the petroleum sector:

\section{Figure 3. Administration of Payment for Land and Building Tax}

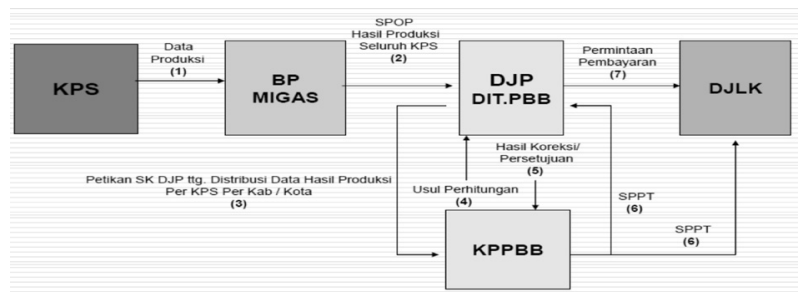

Source: Directorate Directorate of Land and Building Taxes and Fees for Obtaining Rights to Land and or Buildings, Directorate General of Taxes, 2016.

It can be seen in the Petitioner's argument on the Constitutional Court Verdict Number 36/PUU-X/2012 concerning the Testing of Law Number 22 Year 2001 concerning Oil and Gas towards the 1945 Constitution of the Republic of Indonesia, November $13,2012$. 
The Directorate General of Financial Institutions then requests Bank Indonesia to book the portion of the obligation to Deposit Net Business Receipts as the Land and Building Tax revenues, as illustrated below:

Figure 4. Transfer of Deposit of Net Business Receipts

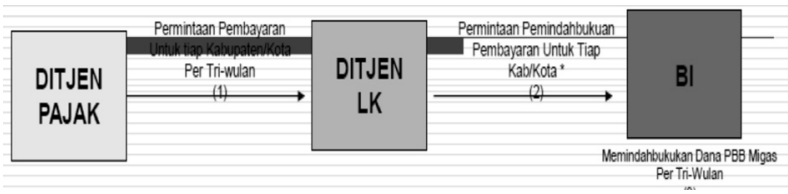

Source: Directorate General of Taxes, 2016.

The assume and discharge scheme is conceptually contrary to the most fundamental principle in state levies, that is, the state may not pay taxes for itself. Far behind is in an era where Pertamina is the controller of petroleum operations management in Indonesia, the fulfillment of tax obligations is done in a unique way. In this context, tax payments are replaced by payments of a certain amount of revenue from the State Company. The legal basis is Government Regulation in Lieu of Law No. 44 Number 1960 in Article 15 paragraph (1), regulating: "Mining holders pay to defined contribution countries, exploration and/ or exploration fees and/or other payments related to granting mining authority". Subsequently, paragraph (2) states, "The details and magnitude of the state levies mentioned in paragraph (1) above are regulated by Government Regulation".

There is also Law No. 8 of 1971 which in Article 15 stipulates that state levies born from upstream oil businesses do not need to be deposited into the State Treasury because the State Company has deposited: ${ }^{10}$

a. $60 \%$ of net operating income for the results of the operations of the State Company itself;

b. $60 \%$ of net operating income for the results of PSC before sharing between the Company and the Contractor; c. all results of the State Company obtained from the Work Agreement;

d. $60 \%$ from the receipts of Company State bonuses obtained from the results of PSC.

The above norms can be illustrated as follows:

Figure 5. The State Receipt Flow of the Era Government Regulation in the Lieu of Law No. 44 of 1960 and Law No. 8 of 1971

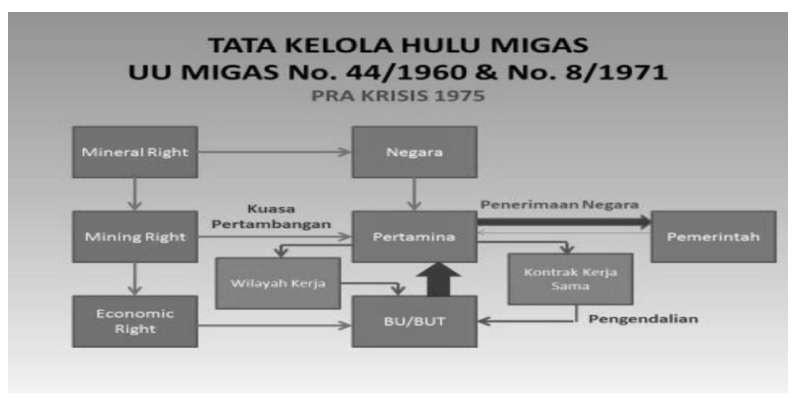

Source: Rachmat Sudibyo, 2014.

Based on the illustration, it can be seen that the four types of payment above are considered as a replacement that frees the State Company and the Contractor from the tax obligation. The problem is that the method above is contrary to the method of payment of taxes that is commonly known. There are five methods that can end tax debt, namely payment, compensation, expiration, release, and deletion. A method similar to the provisions in the Government Regulation in the Lieu of Law No. 44 of 1960 and Law No. 8 of 1971 mentioned above is compensation. However, tax compensation cannot be billed outside the tax field. As an example of compensation can be done for example a taxpayer who has excess tax payments in the previous year can compensate for the payment of taxes this year.

The picture above also shows that the contractor is deemed to have fulfilled his tax obligations if he has deposited the proceeds from the sale of oil and gas to the state. ${ }^{11}$ This has implications for the position of Taxpayers and Tax

10 See Article 14 paragraph (1) U of Law Number 8 of 1971 concerning State Oil and Gas Development Companies (State Gazette of the Republic of Indonesia of 1971 Number 76, Supplement to the State Gazette of the Republic of Indonesia Number 2971). 
Insurers. Taxpayers according to Article 1 Number 2 of Law No. 28 Number 2007 concerning General Provisions and Tax Procedures are "Individuals or entities, including taxpayers, tax cutters, and tax collectors, who have taxation rights and obligations ...". Whereas the Tax Insurer is "an individual or entity responsible for paying taxes, including representatives who exercise rights and fulfill taxpayer obligations ...".

After the enactment of the Government Regulation a quo on December 20, 2010 a change in the payment mechanism of the United Nations from the initial burden of the Government was changed to become a burden with the Government and Contractors by recording the tax payment as a component of costs. This was stated in the Estimated point b No. 76/PMK.03/2013 of 2013 concerning the Tax Administration of Land and Mining Sector Buildings for Petroleum, Natural Gas, and Geothermal Mining.

Contractors operating under the PSC that have been signed since the PP were enacted using a reimbursement scheme, where taxes are paid in advance by the Contractor and will be calculated as the costs to be returned to the Contractor. So using the mechanism of repayment from the Government to the Contractor.Regulations concerning the components of costs that can be provided by Cost Recovery are contained in Government Regulation Number 79 of 2010. In Article 2 of the Government Regulation $a$ quo it is also affirmed that provisions regarding operating costs that can be given cost recovery apply to production sharing contracts and service contracts in upstream business oil and gas. The contractor recovers the operating costs incurred in accordance with the work plan and budget that was previously approved by the Implementing Agency, whose authority is currently held by SKK Migas, after the work area produces commercial production.
Operating costs that can be proposed for cost recovery include, among others: ${ }^{12}$

a. Exploration Operation Costs Operating costs that can be given cost recovery during the Exploration period include:

1) Drilling Costs consist of:
a) Costs for exploration drilling; and
b) Development drilling costs.

2) Geological and geophysical costs consist of:
a) Cost of geological research; and
b) Cost of geophysical research.

3) General and administrative costs of exploration activities; and

4) cost of depreciation.

b. Exploitation Operating Costs

1) Direct cost for production:
a) Oil; and
b) Gas.

2) Processing costs of gas;

3) Utility, covers:
a) Cost of equipment for production and maintenance of equip- ment; and

b) Costs of steam, water and electricity.

4) General and administration costs in the exploitation activities; and

5) Cost of depreciation.

c. General and administrative costs for exploration and exploitation activities consist of:

1) administrative and financial costs;

2) employee costs;

3) material service costs;

4) transportation costs;

5) general office costs; and

6) indirect taxes, regional taxes, and regional levies.

\footnotetext{
11 Appendix of the Regulation of the Minister of Finance of the Republic of Indonesia Number 124 / PMK.02 / 2016 concerning Technical Guidelines for Accounting for Non-Tax State Revenues from Upstream Oil and Gas Business Activities (Official Gazette of the Republic of Indonesia Year 2016 Number 1176).

12 See Article 11 of Government Regulation Number 79 of 2010 concerning Operating Costs That Can Be Returned and Treatment of Income Taxes in the Upstream Oil and Gas Business Field (State Gazette of the Republic of Indonesia of 2010 Number 139, Supplement to the State Gazette of the Republic of Indonesia Number 5173).
} 
d. Additional costs consist of:

1) the cost of moving gas from the production point to the point of delivery; and

2) Costs for upstream business operations activities.

The scope of explicit indirect taxes is specified in the General Explanation, which includes: Value Added Tax, Import Duty and Land and Building Tax. Further said, indirect taxes before the enactment of Government Regulation Number 79 of 2010 become a burden on the Government or called assume and discharge. After the enactment of the Government Regulation a quo was changed so that it became a burden with the Government and contractors by recording the payment of indirect taxes as a component of costs.

The philosophy of the reimbursement mechanism is because of the existence of cost recovery. Returns on operating costs make the country domicile as the owner of the Contractor's assets. This logic is affirmed by the provisions in Article 4 paragraph (1) Government Regulation No. 79 of 2010, states: "All goods and equipment purchased by contractors in the context of petroleum operations are state-owned goods whose guidance is carried out by the Government and managed by the Executive Agency (SKK Migas)."

The mechanism above shows that the payment of Land and Building Taxes is not merely a burden on the government, as happened in the assume and discharge scheme. Land and Building Taxes become a shared burden between the government and the Contractor because Land and Building Tax is calculated in cost recovery. This means that the fulfillment of Land and Building Tax is taken from oil and gas revenues (gross revenue), after which the remaining receipts will be divided (Equity to be Split) between the government and the Contractor.
However, the fulfillment of the Land and Building Tax will automatically reduce the government's share.

Other things are related to the reduction of Land and Building Taxes for Contractors who are still in the exploration stage as stipulated in the Minister of Finance Regulation Number 267/ PM.011/2014 concerning Reduction of Land and Building Mining Taxes for Oil and Gas Mining in the Exploration Stage (Regulations Minister of Finance Number 267/2014). The Land and Building Tax collected in the petroleum mining sector in Indonesia is the Land and Building Tax on the earth and / or buildings within the area used for petroleum mining businesses. For the imposition of this Land and Building Tax, for Land and Building Taxpayers of Oil and Gas Tax that is still in the exploration stage can be given a reduction in the Land and Building Tax on the body of the earth. ${ }^{13}$ This reduction in Land and Building Taxes is given to taxpayers on land and building tax on oil and gas owed and is listed in the Obligatory Tax Return for the earth's body. This deduction is given in the amount of $100 \%$ (one hundred percent) of the payable Oil and Gas Land and Building Tax. ${ }^{14}$ This reduction in Land and Building Tax is given for the Land and Building Tax Tax Return Notification from the 2015 tax year. ${ }^{15}$

Taxpayers who can be given a reduction in Oil and Gas Land and Building Tax are taxpayers who meet the conditions, among others: ${ }^{16}$

a. Taxpayers who sign a cooperation contract after the enactment of Government Regulation Number 79 of 2010 concerning Operating Costs that $\mathrm{Can}$ Be Returned and the Income Tax Treatment in the Upstream Oil and Gas Sector;

13 See Article 2 of the Minister of Finance Regulation Number 267/PM.011/2014 concerning Reduction of Land and Building Mining Sector Taxes for Petroleum and Natural Gas Mining (State Gazette of the Republic of Indonesia Year 2014 Number 2051).

14 See Article 3 of the Minister of Finance Regulation Number 267/PM.011/2014 concerning Reduction of Land and Building Mining Sector Taxes for Petroleum and Natural Gas Mining (State Gazette of the Republic of Indonesia Year 2014 Number 2051).

15 See Article 7 of the Minister of Finance Regulation Number 267/PM.011/2014 concerning Reduction of Land and Building Mining Sector Taxes for Petroleum and Natural Gas Mining (State Gazette of the Republic of Indonesia Year 2014 Number 2051).

16 See Article 4 of the Minister of Finance Regulation Number 267/PM.011/2014 concerning Reduction of Land and Building Mining Sector Taxes for Petroleum and Natural Gas Mining (State Gazette of the Republic of Indonesia Year 2014 Number 2051). 
b. Taxpayers who submit tax returns; and

c. Taxpayers who attach a recommendation letter from the Minister who runs a business in the field of petroleum and natural gas business activities stating that the Oil and Gas Land and Building Tax object is still in the exploration stage.

The reduction in land and building tax exploration stage can be given annually for a maximum period of 6 (six) years, starting from the date of the signing of the cooperation contract between the cooperation contractor in the field of oil and gas mining with the agency or agency whose task and authority is holding oil and gas mining business activities. This period can be extended for a period of 4 (four) years. This extension can be given as long as there is a recommendation letter from the minister who organizes government affairs in the field of oil and gas business activities which states that the object of Land and Building Tax over Oil and Gas is still at the exploration stage. ${ }^{17}$

Based on the Tax Object Notice and a recommendation letter from the minister who administers government affairs in the field of oil and gas business activities, the Tax Service Office issues a Payable Notification Letter of Land and Building Tax by stating the amount of Reduction in Land and Building Taxes ${ }^{18}$ Inclusion of the amount of reduction in Land and Building Taxes in the Payable Notification Letter of Land and Building Tax is evidence of the reduction of the Land and Building Tax. ${ }^{19}$

The Land and Building Tax reduction in the oil and gas mining sector at the exploration stage can be interpreted as a form of tax incentives to attract potential investors to carry out exploration activities and find new petroleum mining areas in Indonesia. Given that petroleum is a vital energy source for the people of Indonesia and even the world, then exploration activities for new mining businesses are needed to ensure the availability of energy reserves.

Petroleum exploration activities are activities that require sophisticated technology and have a high level of risk. From the investor's point of view, it will certainly feel heavy if the large capital requirements and high risks in exploration activities, still have to be charged with the Land and Building Tax levy with a number that is not classified as small. Whereas on the other hand, in exploration activities there is no oil that can be transported from the bowels of the earth and become commercial products which means that at the exploration stage the Contractor has not yet received revenue from petroleum production. When faced with reality in the field, the imposition of the Land and Building Tax for petroleum exploration has a huge impact on investors and leads to low investor interest in conducting exploration activities in Indonesia. Thus, Financial Minister Regulation Number 267/2015 which provides a reduction of the United Nations to the body of the earth up to $100 \%$ (one hundred percent) for contractors who are still in the exploration stage is the right policy if based on the argument that there is no oil production taken from the earth's body and efforts to attract petroleum exploration in Indonesia.

\section{Background of PSC Cost Recovery Amandment into PSC Gross Split}

Ariana Soemanto and Annisa Deasy Ratnasari revealed the background of the scheme change from Cost Recovery to Gross Split in the article "9 Indonesian Upstream Oil and Gas Phenomenon, Opportunity to Improve Investment Climate with Gross Split Oil and Gas Contract". These things include:

a. $\quad$ Oil Prices Fluctuate In July 2014 oil prices reached US \$

\footnotetext{
17 See Article 5 of the Minister of Finance Regulation Number 267/PM.011/2014 concerning Reduction of Land and Building Mining Sector Taxes for Petroleum and Natural Gas Mining (State Gazette of the Republic of Indonesia Year 2014 Number 2051).

18 See Article 6 par. (1) of the Minister of Finance Regulation Number 267/PM.011/2014 concerning Reduction of Land and Building Mining Sector Taxes for Petroleum and Natural Gas Mining (State Gazette of the Republic of Indonesia Year 2014 Number 2051).

19 See Article 6 par. (2) of the Minister of Finance Regulation Number 267/PM.011/2014 concerning Reduction of Land and Building Mining Sector Taxes for Petroleum and Natural Gas Mining (State Gazette of the Republic of Indonesia Year 2014 Number 2051).
} 
106 per barrel, then in February 2016 oil prices dropped to US \$26 per barrel which was the lowest oil price for the past ten years. With the Cost Recovery scheme, when the oil price rises, the contractor will get a bigger windfall profit from the government. On the other hand, if the oil price is low, the contractor will also suffer greater losses.

b. The survey results reflect the condition of oil and gas investments in Indonesia is not very good. A 2016 survey by the Fraser Institute Petroleum Survey put Indonesia ranked 76th out of 96 countries surveyed.

c. The contribution of oil and gas to state revenues declined from year to year. In the 1970 s it reached $70 \%$, in $2010-$ 2014 it dropped to $20 \%$, in 2016 it reached $5 \% .{ }^{20}$

d. Oil and gas reserves declined from 4.23 billion barrels in 2010 to 3.6 billion barrels in 2015 .

e. The low oil and gas exploration activities, the number decreased from 70 activities in 2010 to 16 activities in 2015. The reason besides the low oil price is the length of procedure for submitting oil and gas exploration.

f. Oil production declined, around 1.5 million barrels per day in 1977 and 1995 decreased by 829 thousand barrels per day in 2016.

g. The long procedure for oil and gas production, after the discovery of oil and gas reserves takes a long time to start its first production. In the 2000s it took 15 years which previously only took 5 years in the 1970s. This is inseparable from the weakness of the Cost Recovery scheme where the procurement of goods and services is necessary through the procedures and approval of SKK Migas.

h. Complex Cost Recovery bureaucracy. The Cost Recovery Scheme has a system of returning operating costs that has been issued by the contractor. The types of operating costs that will be returned by the state are often debated.
Because the scope is very broad including the cost of drilling wells to office stationery. Procurement of contractor goods and services with this scheme requires a long bureaucracy because of the need for approval from SKK Migas. Cost Recovery relates to state revenues, so it becomes a discussion in the preparation of the State Budget. Besides being full of political interests, Cost Recovery is not efficient because it will ultimately become the responsibility of the state.

i. Cost Recovery Overruns In the 2016 State Budget, Cost Recovery is planned to be around US \$ 8.5 billion, but the realization reaches US \$ 11.5 billion.

The scheme change from Cost Recovery to Gross Split is a good desire from the Minister of Energy and Mineral Resources to fulfill the principle of justice and efficiency in the management of the oil and gas sector. The operating costs initially incurred by contractors are often inefficient and seem wasteful. Later the operating costs will be returned by the state, so the contractor is not encouraged to carry out operational cost efficiency. With these problems related to Cost Recovery, reforms in upstream oil and gas business activities are needed.

\section{Administration of Land and Building Tax in the Era Production Sharing Contract Gross Split}

On January 16, 2017 Minister Regulation of Energy and Mineral Resources Number 8 of 2017 concerning PSC Gross Split was promulgated. The Production Sharing Contract scheme between countries and investors has changed from before using Cost Recovery to Gross Split. Article 1 Number 7 Minister Regulation a quo defines the PSC as "Contract based on the principle of gross division of production without a mechanism for returning operating costs". Based on Articles 24 and 25, the PSC Gross Split is implemented with 
the following provisions:

e. The contractor who signs the PSC prior to the entry into force of this Minister Regulation continues to use the Gross Split scheme until the expiration date of the relevant PSC. But for him, he was given space to independently propose changes to the PSC Gross Split;

f. For the Contractor who signs the PSC after the entry into force of this Permen to manage the new working area and has never been operated (virgin area), PSC Gross Split applies;

g. For the Contractor who signs the PSC after the entry into force of this Permen to manage the work area that has expired and has not been extended (take over), PSC Gross Split applies; and

h. For Contractors who have expired and extended their contract period, they can choose the form of PSC cost recovery or propose changes to the PSC Gross Split.

This new contract was motivated by the government's intention to improve the efficiency and effectiveness of the pattern for oil and gas production. It is not surprising that state revenue is one of the main focuses. The argument can be seen from the provisions of Article 3 which state that the Gross Split Production Sharing Contract must contain at least the basic provisions, including state revenues. Furthermore, Article 11 paragraph (1) regulates: "State Revenues in PSC Gross Split as referred to in consist of: parts of the country; bonuses; and Contractor income tax." In paragraph (2) regulated, "In addition to the State Revenues as referred to in paragraph (1), the Government shall obtain indirect taxes in accordance with the provisions of the legislation." One type of indirect tax in the oil and gas sector is the Land and Bulding Tax, as previously elaborated.

The most fundamental changes due to the elimination of the return on operating costs, one of which is the change in tax payments. In the previous period, payment of indirect taxes used the assume and discharge and reimbursement schemes. Both can be enforced due to the implementation of a mechanism for returning operating costs, but not for the PSC Gross Split because the return on operating costs has been written off so that all types of taxes will be paid directly by the Contractor from the receiving part.

Regulation of the Minister of Energy and Mineral Resources No. 8 of 2017 unfortunately itdoes not regulate the implementation of tax obligations for Contractors operating using PSC Gross Split. Moreover, there are no provisions in article by article Candy which mandates further arrangements. Even so, the mechanism for paying indirect taxes including the United Nations can be analyzed by linking the provisions of Article 13 and Article 14. Such Article 13 regulates "Contractors are obliged to pay income tax in accordance with the provisions of legislation on income tax treatment in the field of Upstream Oil and Gas Business Activities". Parallel to that Article 14 states "Operating costs incurred by the Contractor can be calculated as a deduction from the Contractor's income tax." Furthermore, the author tries to link the two provisions above with the provisions of other relevant legislation, namely Government Regulation No. 27 of 2017 and Law No. 36 of 2008 concerning the Fourth Amendment to Law Number 7 of 1983 concerning Income Tax. The Government Regulation a quo, especially in the Article 11 paragraph (4) letter $\mathrm{f}$ categorizes indirect taxes as part of operating costs, precisely as general and administrative costs for Exploration and Exploitation activities. Associated with the provisions of Article 14 above, then a certain amount of unpaid Land and Building Tax paid by the Contractor to the state treasury is considered a fiscal burden that will be calculated as a deduction from income tax. Thought is reinforced by the construction of the Income Tax calculation arrangement in Article 6 of the Income Tax Law, that the amount of taxable income for domestic taxpayers and it is determined based on gross income less costs to obtain, collect and maintain 
income, including taxes paid by the Taxpayer. ${ }^{21}$

Based on the elaboration above, it can be concluded several things related to the payment of outstanding Land and Building Taxes during the Gross Split Production Sharing Contract period. First, the Land and Building Tax is paid directly by the Contractor from the portion of his income from upstream oil and gas activities. Second, the United Nations is no longer the responsibility of the government, either in whole or in part as it is in the assume and discharge and reimbursement schemes. Third, the Land and Building Tax that has been deposited into the state treasury can be calculated as a deduction from the Contractor's gross income in order to calculate the amount of Taxable Income. The flow of payments for Land and Building Taxes can be described in the figure below.

\section{Figure 6. Calculation of Land and Building Tax for PSC Gross Split}

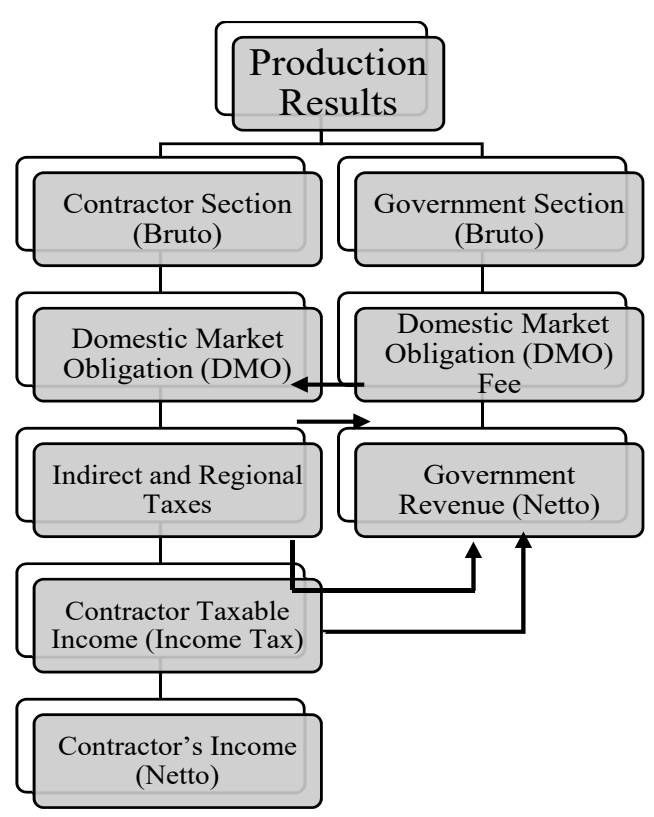

Source: Composed by Author.

Even though there is no return on operating costs, the Gross Split Production Sharing Contract does not necessarily harm the Contractor. The determination of profit sharing for the Contractor on this contract is far greater than what is stated in the conventional contract. Article 5 paragraph (1) Regulation of the Minister of Energy and Mineral Resources No. 8 of 2017 regulates the distribution of petroleum by $57 \%$ of the State and $43 \%$ of the Contractor, while in conventional contracts $85 \%$ of the State and $15 \%$ of the Contractor.

\section{Conclusion}

Based on the discussion above, it can be concluded that, First, the fulfillment of Land and Building Tax obligations in the oil and gas mining sector in the era of Production Sharring Contract Cost Recovery uses two different schemes, for contractors operating under the PSC signed before 2010 with contractors operating under the PSC signed post 2010. For contractors operating under the PSC signed before 2010 using assume and discharge or transfer schemes, based on the provisions of the Minister of Finance Decree No. 451/KMK.04/1997 concerning Management of Land and Building Tax Object Data Oil and Gas and Geothermal Mining and Payments as well as Director General of Tax Decree No. Kep-19/Pj.6/1997 concerning Procedures for the Administration of Tax Objects for Land and Buildings for Oil and Gas and Geothermal Mining and Payments.

Second, as for contractors operating under the PSC signed after 2010 using a reimbursement scheme based on the provisions of PP 79/2010 concerning Operating Costs that can be Returned and Income Tax Treatment in the Upstream Oil and Gas Business Field. Third, the reimbursement and assume and discharge scheme cannot be applied to PSC Gross Split which are regulated under the provisions of the Minister of Energy and Mineral Resources No. 52 of 2017 concerning Amendments to Regulation of the Minister of Energy and Mineral Resources No. 8 of 2017 concerning PSC Gross Split. In it it is stipulated that the operating

\footnotetext{
21 See Article 6 of Law Number 36 of 2008 concerning the Fourth Amendment to Law Number 7 of 1983 concerning Income Tax (State Gazette of the Republic of Indonesia of 2008 Number 133, Supplement to the State Gazette of the Republic of Indonesia Number 4893) positions taxes except income tax directly as costs or indirectly related to business activities that can be used to reduce gross income in order to calculate the amount of Taxable Income.
} 
costs incurred by the Contractor (including the Land and Building Tax) are a deduction of the Contractor's income in calculating Income Taxes. The implementation is subject to the provisions of Article 6 paragraph (1) of Law No. 36 of 2008 concerning Income Tax which states tax except income tax is considered as the cost of obtaining, collecting, and maintaining income, so that it can be deducted from gross income.

The author also gives some suggestions, namely, First, the PSC Gross Split arrangement in general needs to be reviewed, especially because this form of contract is not attractive to investors. It appears in the absence of oil and gas working areas that have been selling since 2016-2017. There is no new upstream investment in 2017, operating activities that are limited to those carried out by the Contractor PSC cost recovery. The description below describes upstream investment sluggishness:

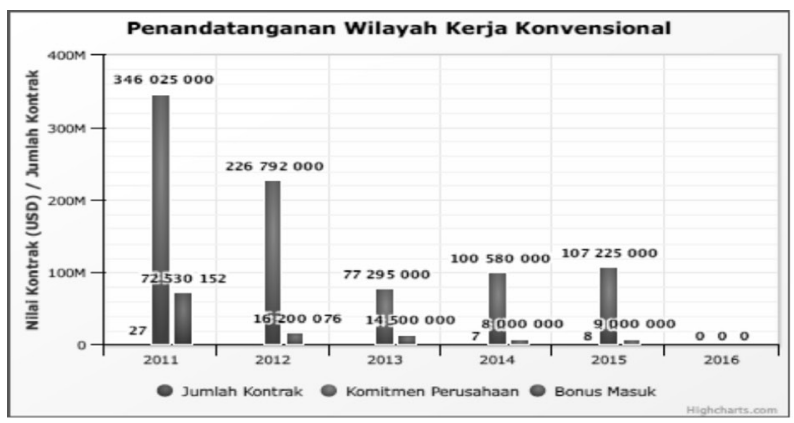

\section{Investasi Hulu Migas 2016} Persentase

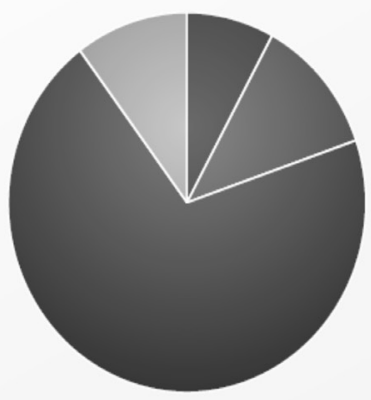

Eksplorasi Pengembangan Produksi Investasi Hulu Migas 2017 Persentase

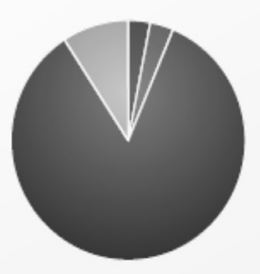

Eksplorasi Pengembangan Produksi Administras

Second, up to now the government has not made provisions for the reduction of Land and Building Tax on the earth's body at the stage of oil exploration for the PSC Gross Split Contractor, even though this incentive is given to the PSC Contractor cost recovery. In order to create equal treatment for all oil and gas contractors in Indonesia, the arrangement should be immediately stipulated.

\section{REFERENCES}

\section{A. Books}

Lubiantara, Benny, 2012, Ekonomi Migas: Tinjauan Aspek Komersial Kontrak Migas, Gramedia, Jakarta.

\section{B. Research Results}

Ariyati, Ety Syamsiah, 2010, Analisis KetentuanKetentuan di Production Sharing Contract Indonesia dalam Kaitannya dengan Penerimaan Negara Minyak dan Gas Bumi, Thesis, Universitas of Indonesia.

Shobah, Shofia, 2015, Cost Recovery dalam
Kontrak Kerjasama Minyak dan Gas Bumi di Indonesia Ditinjau dari Hukum Kontrak Internasional, Thesis, Faculty Law, Brawijaya University.

\section{Internet Articles}

Soemanto, Ariana, and Annisa Deasy Ratnasari, "9 Fenomena Hulu Migas Indonesia, Peluang Memperbaiki Investasi dengan Kontrak Migas "Gross Split", https://www. pinsentmasons.com/PDF/2017/Asia\%20 Pacific/Indonesias-new-Gross-Split-PSC. 
pdf, accessed on 11 September 2017.

\section{Government Regulations}

Law Number 8 of 1971 concerning State Oil and Gas Development Companies (State Gazette of the Republic of Indonesia of 1971 Number 76, Supplement to the State Gazette of the Republic of Indonesia Number 2971).

Law Number 22 of 2001 concerning Oil and Gas (State Gazette of the Republic of Indonesia of 2001 Number 136, Supplement to the State Gazette of the Republic of Indonesia Number 4152).

Law Number 36 of 2008 concerning the Fourth Amendment to Law Number 7 of 1983 concerning Income Tax (State Gazette of the Republic of Indonesia of 2008 Number 133, Supplement to the State Gazette of the Republic of Indonesia Number 4893).

Government Regulation Number 79 of 2010 concerning Operating Costs Which Can Be Returned and Treatment of Income Tax in the Upstream Business Field of Oil and Gas (State Gazette of the Republic of Indonesia of 2010 Number 139, Supplement to the State Gazette of the Republic of Indonesia Number 5173).
Minister of Finance Regulation Number 124/ PMK.02/2016 concerning Technical Guidelines for Accounting for Non-Tax State Revenues from Upstream Oil and Gas Business Activities (Official Gazette of the Republic of Indonesia Year 2016 Number 1176).

Minister of Finance Regulation Number 267/ PM.011/2014 concerning Reduction of Land and Building Mining Sector Taxes for Petroleum and Natural Gas Mining (State Gazette of the Republic of Indonesia Year 2014 Number 2051).

Minister of Energy and Mineral Resources Regulation Number 08 of 2017 concerning Gross Split Production Sharing Contracts (Official Gazette of the Republic of Indonesia Year 2017 Number 116).

\section{E. Court Verdict}

Constitutional Court Verdict Number 36/ PUU-X/2012 concerning the Testing of Law Number 22 Year 2001 concerning Oil and Gas towards the 1945 Constitution of the Republic of Indonesia, November 13, 2012. 